Baiba Grase, Mg. iur.

Latvija

\title{
ADVOKĀTA LOMA MEDIĀCIJAS PROCESĀ
}

\section{ROLE OF LAWYER IN MEDIATION PROCESS}

\begin{abstract}
Summary
This report examines the role of attorney in mediation and analyses the possible involvement of an attorney in each stage of mediation, evaluating both the limits of providing legal assistance and the manner in which the attorney participates in mediation. The attorney may have a critical influence in resolution of the conflict involving his or her client. Special attention is paid to the difference between mediation and legal proceedings, and the importance of the attorney acquiring additional knowledge, skills, experience, and behavior patterns to support the client in the process of mediation.
\end{abstract}

Atslēgvārdi: advokāts, mediācija, alternatīva strīdu risināšana (ADR), ārpustiesas strīdu risināšana

Keywords: attorney, mediation, alternative dispute resolution (ADR), extrajudicial dispute resolution

Raksta mērḳis ir analizēt dažādās advokāta lomas mediācijas procesā un tām nepieciešamās zināšanas un prasmes.

Advokāta profesija ir viena no senākajām - šis institūts sastopams jau Senajā Grieḳijā un Romā. Sākotnēji advokāti bija tiesību aizstāvji un palīgi tiesā. Tikai vēlāk tie kḷuva arī par personas pārstāvjiem. Tādējādi advokāts izsenis ir saistīts ar tiesām, sniedzot padomus personām strīda atrisināšanā un pārstāvot personas tiesas procesā. ${ }^{1}$

Modernajā pasaulē arvien biežāk par visefektīvāko konflikta risināšanas veidu tiek uzskatīts dialogs ar mērḳi rast kompromisu un nonākt pie konsensa, nevis uzvarēt konfliktā un pierādīt savu taisnību. Viena no tiesvedỉbai alternatīvām strīdu risināšanas metodēm ir mediācija - process, kurā konfliktā iesaistītās puses ar mediatora palīdzību sarunu un sadarbības procesā meklē risinājumus un cenšas rast savstarpēji pien,emamu vienošanos strīdu jautājumos.

Mediācija nav patstāvīga zinātne, tās pieeja ir starpdisciplināra. Mediācija ir process, kas vērsts nevis uz patiesības noskaidrošanu, bet uz nākotni, uz domstarpību atrisināšanu pēc būtības, uz problēmu risinājumu un sadarbību nākotnē, n,emot vērā pušu patiesās intereses un vajadzības. Savukārt strīda risināšanai tiesā ir daudz abstraktāks mērḳis - noskaidrot objektīvo patiesību, fokusējoties uz pagātnē notikušo. ${ }^{2}$

Litvins G. Advokātu process: neatbildētie jautājumi. Jurista Vārds, 2015. gada 7. aprīlis, Nr. 14 (866). Feehily R. The role of the lawyer in the commercial mediation process: a critical analysis of the legal and regulatory issues. Pieejams: https://www.academia.edu/36534721/The_Role_of_the_Lawyer_ in_the_Mediation_Process_A_Critical_Analysis_of_the_Legal_and_Regulatory_Issues [aplükots 2019. gada 9. maijā]. 
Arvien vairāk advokātu apgūst mediatora prasmes un piedāvā mediācijas pakalpojumu. Latvijā nav vienotas mediatoru uzskaites, tādēl nav iespējams pateikt, cik zvērinātu advokātu ir arī mediatori. Sertificētu mediatoru skaitā no 52 sertificētiem mediatoriem 14 ir zvērināti advokāti (2019. gada 1. jūlija dati). Tomēr autore vēlas uzsvērt, ka advokāta loma mediācijā nav ierobežota ar kḷūšanu par mediatoru un advokāta kā mediatora darbība ir jau cita raksta tēma.

Latvijas Republikas Advokatūras likumā noteikts, ka advokāts ir neatkarīgs un profesionāls jurists, kas sniedz juridisko palīdzību, aizstāvot un pārstāvot tiesā un pirmstiesas izmeklēšanā personu likumīgās intereses, sniedzot juridiskas konsultācijas, gatavojot juridiskus dokumentus un veicot citas juridiskas darbības. ${ }^{3}$ Šis likumā ietvertais formulējums aptver plašu advokāta darbības lauku, to skaitā arī juridiskās palīdzības sniegšanu klientam mediācijas procesā.

\section{Advokāta lomas mediācijas procesā}

Atšķirīga ir advokāta iesaiste katrā mediācijas procesā. Advokāta loma var saistīties tikai ar klienta informēšanu, konsultēšanu pirms mediācijas vai visā mediācijas procesa laikā vai pat sniegties līdz advokāta klātienes dalībai mediācijas procesā un klienta interešu pilnīgai pārstāvībai ${ }^{4}$ Turpmāk rakstā aplūkotas advokāta iespējamās lomas visā mediācijas procesa laikā.

\subsection{Advokāts - mediācijas ieteicējs}

Koncepcijā "Mediācijas ieviešana civiltiesisku strīdu risināšanā” teikts: "Sabiedrībā pakāpeniski rodas vēlme pēc pašregulācijas, tai skaitā nepieciešamības pašiem pieņemt sev saistošus lēmumus, uzṇemties atbildību par strīda atrisinājumu. Lìdz ar to prognozējams, ka sabiedrībā pieprasījums pēc alternatīva strīdu risināšanas procesa palielināsies, taču, lai strīda puses vienošanos pēc savas iniciatīvas mēginātu panākt mediācijas ceḷā, būtiska ir mediācijas atpazīstamības un uzticēšanās tai veicināšana." ${ }^{5}$

Tieši advokāts var būt tā persona, kas klientam iesaka strīda risināšanu mediācijas procesā, turklāt gan situācijā, kad konflikts jau radies, gan darījumu slēgšanas procesā, iesakot klientam iekḷaut līgumā mediācijas klauzulu. Mediācijas likuma 8. panta pirmā daḷa nosaka, ka puses var mutiski vai rakstveidā vienoties par mediācijas izmantošanu, lai risinātu domstarpības, kas jau radušās vai varētu rasties nākotnē. Minēto vienošanos kā mediācijas klauzulu var ietvert jebkurā rakstveida līgumā. ${ }^{6}$

3 Latvijas Republikas Advokatūras likums: LV Likums. Latvijas Republikas Saeimas un Ministru Kabineta Ziņotājs, 1993. 19. augusts, Nr. 28.

4 Guidelines For Lawyers In Mediations. Law Council of Australia. Pieejams: file:///C:/Users/user/ Downloads/1108-Policy-Guideline-Guidelines-for-Lawyers-in-Mediations\%20(3).pdf [aplūkots 2019. gada 9. maijā].

5 Koncepcija "Mediācijas ieviešana civiltiesisku strīdu risināšanā", Ministru kabineta 2009. gada 18. februāra rīkojums Nr. 121.

6 Mediācijas likums: LV Likums. Latvijas Vēstnesis, 2015. 4. jūnijs, Nr. 108 (5168). 
Sniedzot juridisko palīdzību, advokātam jāvērtē, kāds strīda risināšanas veids klienta lietai būtu visatbilstošākais. Minētais izriet arī no Latvijas Zvērinātu advokātu kolẹgijas apstiprinātā Advokātu ētikas kodeksa 3.7. punkta, kas nosaka, ka advokātam, ja tas ir klienta interesēs, jācenšas panākt lietas atrisinājumu ārpustiesas kārtībā pirms lietas iztiesāšanas uzsākšanas. ${ }^{7}$

Lai veicinātu mediācijas izmantošanu, būtiska nozīme ir advokātu izpratnei par tās piedāvātajām iespējām, bet izpratni veido zināšanas, kādas alternatīvas tiesvedībai iespējams izmantot, kādi katrā no tām var būt ieguvumi, kādi ierobežojumi. Šādas zināšanas l̦auj kritiski izvērtēt, kāda pieeja vislabāk atbilstu situācijai, ar kādu saskāries klients, kā arī izvēlēties vislabāko iespējamo procesu. Pat situācijā, kad klients izvēlēsies tiesāšanos, viņš būs informēts un tas būs viṇa apzināts lēmums. ${ }^{8}$

\subsection{Advokāts - konsultants par mediācijas procesu}

Pēc lēmuma par strīda risināšanu mediācijas procesā pien,emšanas advokāts vispirms var konsultēt klientu mediatora izvēlē, n,emot vērā mediatora pieredzi, kvalifikāciju, izglīiību un speciālās zināšanas, kas var būt noderīgas konkrētā strīda risināšanā. Pats galvenais kritērijs, izvēloties vienu mediatoru no daudziem, ir tas, cik labi tas spēs saprasties ar pusēm, to skaitā arī ar klientu. Vai klients vairāk uzticēsies mediatoram, kurš agrāk bijis valdes loceklis kapitālsabiedrībā vai arī pieredzes bagāts tiesvedības speciālists? ${ }^{9}$ Kāds ir klienta temperaments, kādas ir autoritātes? Piemēram, autores praksē bijusi situācija, kad mediācija nav izdevusies, jo, pēc klienta domām, tā atgādinājusi psihoterapiju un mediators runājis klusinātā balsī, kas klientā izraisījusi milzu pretestību. Šādi blakus aspekti tikai sākotnēji var šķist otršķirīgi, jo mediatora izvēlei ir liela nozīme tajā, vai mediācijas process izdosies, vai puses uzticēsies procesam. Jāatzīst gan, ka reizēm advokāti ieteikumos var dot priekšroku mediatoriem advokātiem, jo var uzskatīt, ka mediatori ar tiesvedības pieredzi labāk sapratīs viṇu teikto. ${ }^{10}$

Advokātam klients mediācijas procesam ir jāsagatavo. Būtu ieteicams, lai klientam jau pirms procesa uzsākšanas būtu paskaidroti svarīgākie mediācijas procesa principi, klienta tiesības tajā, kā arī sniegta konsultācija par līgumu ar mediatoru. Pirms mediācijas advokāts kopā ar klientu izvērtē lietu, analizē riskus un iespējamos ieguvumus, izrunā iespējamo stratēgiju un to, kādos jautājumos klients ir gatavs atkāpties no savām pozīcijām un kādas ir klienta patiesās intereses. Mediācija ir process, kurā palīdz sasniegt vienošanos, tāpēc gatavošanās mediācijai daudzējādā ziṇā neatškịiras no nopietnu pārrunu plānošanas. Vislielākā atškirīiba starp izlīguma sarunu procesu un

7 Latvijas Zvērinātu advokātu ētikas kodekss. Pieņemts Latvijas Zvērinātu advokātu kopsapulcē 1993. gada 21. maijā; ar grozījumiem, kas izdarīti ar kopsapulces 30.04.2010. lēmumu; izteikts jaunā redakcijā, kas apstiprināts ar 2019. gada 12. aprīla kopsapulces lēmumu.

8 Shako F. K. Teaching Old Dogs New Tricks: Can Lawyers Be Effective At Mediation? Pieejams: https://www.ajol.info/index.php/jolte/article/viewFile/113165/102888 [aplūkots 2019. gada 9. maijā].

9 Golann D. Mediation Advocacy. The role of Lawyers in Mediation. Pieejams: https://www. conflictdynamics.co.za/Files/129/Mediation-Advocacy--the-role-of-lawyers-in-mediation-.pdf [aplūkots 2019. gada 9. maijā].

10 Clark B. Lawyers and mediation. London: Springer, 2012, p. 121. 
mediāciju ir mediatora esamībā. Mediatora klātbūtne nozīmē, ka process dažkārt atgādina divu pušu sarunas, kuras atbalsta mediators, dažkārt - trīspusējas sarunas starp dalïbniekiem un mediatoru. ${ }^{11}$ Gatavojoties mediācijas procesam, ir jānoskaidro, kas ir patiesie tā dalībnieki. Praksē ir situācijas, kad patiesie konfliktā iesaistītie ir otrajā plānā, neredzami. Piemēram, strīdā par bērna dzivesvietu tieši vecvecāki var būt patiesā konfliktā iesaistītā puse. Ja tiesvedības procesā šādā lietā puses būs abi vecāki, mediācijas procesā uz sarunu aicināmi arī vecvecāki, jo tikai šādā gadījumā mediācija būs efektìva.

\subsection{Advokāts - mediācijas procesa dalïbnieks, klienta atbalsta persona}

Mediācijas procesa laikā advokāts var klientu gan konsultēt mediācijas sesiju starplaikos, gan sniegt atbalstu, klātienē piedaloties mediācijā. Priekšnoteikums advokātu klātbūtnei mediācijas procesā ir pušu vienošanās par mediācijas dalībniekiem ${ }^{12}$. Pirms mediācijas advokāts ar savu klientu vienojas, kādos brǐ̌̌os advokāts izteiksies, kāda būs ievadruna, sagatavojas tai. Piemēram, klients var vēlēties pats ievadrunā izklāstīt situāciju, jo viņam svarīgi ir izskaidrot pretējai pusei to, kā jūtas. Citā situācijā klients var vēlēties, lai advokāts runā par visiem jautājumiem, jo jūtas apdraudēts, uzskata, ka emocionāli traumējoša būs konfrontācija ar pretējo pusi vai tās advokātu. ${ }^{13}$ Advokātam jāpaskaidro klientam, ka galvenais mērḳis ir nodrošināt klientam pēc iespējas labāku lietas risinājumu, bet mediācijas sarunu taktika var atšlkirties. ${ }^{14}$

Minot atsevišķus negatīvus aspektus, kas saistīti ar advokātu piedalī̌̌anos mediācijā, jānorāda, ka šādos gadijumos puses mediatoram var pieškịt mazāku lomu, vairāk ieklausīties advokātos. Advokāti mēdz uzṇemties kontroli pār procesu, vilkt robežas, strikti pieturēties pie juridiskajiem argumentiem, noteikt nesamērīgi augstas prasības, noliegt emocijas vai pieņemt lēmumus klientu vietā. Mediācijā advokāta loma ir atbalstīt klientu, būt klāt, bet ievērot arī zināmus nosacījumus, proti, atbalsta personas neiejaucas procesa gaitā, netraucē procesa laikā, izprot procesu. Mediators var dot iespēju izteikt savu viedokli, ja tas nepieciešams, vienoties par pārtraukumu, piemēram, juridiskas konsultācijas sniegšanai klientam. Tā kā mediācijas process bieži vien ir emocionāls, advokātam ir jābūt gatavam arī dažādām emociju izpausmēm, jo emociju pazīšana un pieṇemšana var būt l̦oti nozīmīga konflikta risināšanā. Ja advokāts ar savu rīcību vai attieksmi kavēs pušu emociju izlādi, tas var būtiski ietekmēt un kavēt mediācijas procesu. Taču sagatavota un apzināta atbalsta persona var sniegt neatsveramu palīdzību mediatora darbā. ${ }^{15}$ Advokāta uzvedība gan var kḷūt aktīvāka, ja

11 Golann D. Mediation Advocacy. The role of Lawyers in Mediation. Pieejams: https://www.conflictdynamics.co.za/Files/129/Mediation-Advocacy--the-role-of-lawyers-in-mediation-.pdf

12 Mediācijas likums: LV Likums. Latvijas Vēstnesis, 2015. 4. jūnijs, Nr. 108 (5168) [aplūkots 2019. gada 9. maijā].

13 Sternlight J. R. Lawyers' Representation of Clients in Mediation: Using Economics and Psychology to Structure Advocacy in a Nonadversarial Setting. Pieejams: https://kb.osu.edu/bitstream/ handle/1811/79967/OSJDR_V14N2_269.pdf?sequence=1 [aplūkots 2019. gada 9. maijā].

14 Golann D. Mediation Advocacy . The role of Lawyers in Mediation. Pieejams: https://www. conflictdynamics.co.za/Files/129/Mediation-Advocacy--the-role-of-lawyers-in-mediation-.pdf [aplūkots 2019. gada 9. maijā].

15 Gereiša Z., Kirstuka L., Kḷave E. Mediācija. Jēdzieni. Testi. Lomu spēles. Mācību grāmata. Rīga: Tiesu namu aǵentūra, 2018, 99. lpp. 
nepieciešams nodrošināt, ka klients netiek maldināts, vai kādā veidā piespiests noslēgt vienošanos, kas klientam nodara kaitējumu. ${ }^{16}$ Mediācijas procesā svarīgi klausīties, uzzināt un atkāpties no iepriekš novilktām robežām un nosacījumiem, lai palīdzētu klientam rast vislabāko iespējamo risinājumu, kas ne vienmēr būs vienošanās. Mediācijas sesiju starplaikos ir jāpaskaidro klientam notikušais, jāpalīdz sagatavoties nākamajai sesijai; atsevišķo jeb caucus mediācijas sesiju laikā advokāts var mediatoram izskaidrot, kādas ir klienta vajadzības, kādos jautājumos ir iespējama vienošanās. Šādas atsevišķās sesijas var būt ḷoti noderīgas, jo ḷauj advokātam izteikt mediatoram savu viedokli par strīda perspektīvām un mediatoram dod labāku iespēju izprast problēmu. ${ }^{17}$

\subsection{Advokāts - vienošanās projekta sagatavotājs}

Mediācijai noslēdzoties, nozīmīga advokāta loma ir vienošanās, ja tāda ir panākta, projekta sagatavošanā un saskaņošanā. İpaši svarīgi tas ir gadỉjumā, ja mediatoram nav juridiskās izglìīibas un pieredzes līgumu sagatavošanā. Mediācijas rezultāts nav šauri ierobežots kā tiesvedības procesā, kad jautājums tiek izlemts tikai celtās prasības robežās. Puses var vienoties jautājumos ārpus sākotnējā strīda robežām, radoši. Advokāta uzdevums ir izskaidrot klientam, kādas saistỉbas klients ar vienošanos uzṇemas, varbūtējos riskus, izpildes iespējamību un klienta rīcỉbu, gadījumā, ja noslēgtā vienošanās netiek pildīta. Advokātam šajā vienošanās saskaņošanas fāzē jāizvairās no mediācijā izlemtu jautājumu grozīšanas, ievirzot mediācijas procesu juridisku formulējumu strupcẹ̦ā.

\subsection{Advokāts - pārstāvis mediācijas procesā}

Advokāts mediācijā var būt arī puses pārstāvis. Šādā gadījumā ḷoti svarīgs ir sagatavošanās process, advokāta un klienta savstarpējā uzticēšanās, svarīgi ir noteikt pilnvarojuma apjomu, lēmumu pieņemšanas robežas. Pārstāvot klientu mediācijā, advokātam ir nepieciešama radoša domāšana, darbību saskaņošana ar klientu, uz problēmas risināšanu vērsta darbība. ${ }^{18}$ Gadījumos, kad advokāts mediācijā piedalās kā klienta pārstāvis, pastāv dažādi riski. Piemēram, klients var būt noklusējis savas patiesās intereses, dažādus emocionālus jautājumus. Mediācijas process ir pakārtots tam, lai strīda puses izprastu savas patiesās vajadzības un intereses, lai sasniegtu rezultātu, kurā apmierinātas ir abas puses. Advokāts, visticamāk, argumentēs savu viedokli, pamatojoties tikai uz juridiskiem apsvērumiem, un paliks neatklāti jautājumi, kas, pusēm runājot tieši vienai ar otru, varētu mainīt mediācijas procesa rezultātu. Pārstāvot klientu, advokāts var maldīgi pien̦emt, ka viṇa ieskatā labākais risinājums lietā atbilst klienta patiesajām interesēm.

16 Sternlight J. R. Lawyers' Representation of Clients in Mediation: Using Economics and Psychology to Structure Advocacy in a Nonadversarial Setting. Pieejams: https://kb.osu.edu/bitstream/ handle/1811/79967/OSJDR_V14N2_269.pdf?sequence=1 [aplūkots 2019. gada 9. maijā]

17 Golann D. Mediation Advocacy. The role of Lawyers in Mediation. Pieejams: https://www. conflictdynamics.co.za/Files/129/Mediation-Advocacy--the-role-of-lawyers-in-mediation-.pdf [aplūkots 2019. gada 9. maijā].

18 Menkel-Meadow C. The Lawyer As Consensus Builder: Ethics For a New Practice. Pieejams: https:// www.researchgate.net/publication/47505472_The_Lawyer_As_Consensus_Builder_Ethics_For_a New_Practice [aplūkots 2019. gada 9. maijā]. 
Advokāta uzvedības modelis mediācijā atškiras no tiesvedỉbas vai izlīguma sarunu procesa. Advokātam mediācijā jābūt gatavam būt gan cīnītājam, gan novērotājam. Tas vienmēr būs atkarīgs no konkrētās strīda lietas apstākḷiem, no dažādiem psihologiskiem, ekonomiskiem, stratēgiskiem apstākḷiem, no klienta un advokāta savstarpējās vienošanās, atbildības sadalījuma un uzticēšanās pakāpes. ${ }^{19}$

\section{Advokātam mediācijas procesā nepieciešamās zināšanas un prasmes}

Latvijas Republikā praktizējošiem advokātiem tiek piedāvātas dažādas tālākizglītības programmas, semināri, kuros apgūt mediācijas prasmes, tomēr šādu mācību apmeklēšana ir katra advokāta personīgā izvēle. Mediācijā nozīmīgas ir pušu emocijas, psihologiski, emocionāli, kultūras u. c. nejuridiski aspekti. Ir nepieciešams izmantot dažādus resursus, kas iekḷauj psihologijas, komunikācijas, sociologijas un konfliktu risināšanas teorijas. ${ }^{20}$ Lai veiksmīgi sniegtu juridisko palīdzību mediācijas procesā, ir jāapgūst saskarsmes prasmes, sarunu vadīšanas principi, jāspēj saskatīt un nošķirt, kas ir pušu pozīcijas un kas ir patiesās intereses un vajadzības, jāapgūst aktīva, empātiska klausīšanās, jāmācās atpazìt emocijas un dažādus uzvedības modeḷus, jāspēj līdzsvarot logisko un emocionālo prātu.

Tradicionāli advokāts, strādājot ar klienta lietu, notikumus un personas grupē kategorijās pēc to juridiskā nozīmīguma, domā par tiesībām un pienākumiem, kuri noteikti tiesību normās, fokusējas uz rīcību, nevis personām. Mediācijā svarīgākie jautājumi nav, kas, kur, kad, bet gan - kāpēc. Advokāts nevar apmierināties tikai ar juridisko faktu analīzi. Jārunā ar klientu plašāk - par viṇa vērtībām, izpratni par lietu, jānoskaidro, kāpēc viṇš vēlas konkrētu risinājumu. Tikai tā ir iespējams uzzināt, kāds rezultāts radīs klienta apmierinātību. Ir diezgan sarežğiti saprast, kad puse ir apmierināta. Pareizāk sakot, runa ir par jautājumu, kad puse, pakalpojumam beidzoties, būs apmierināta, tātad par to, kā panākama apmierinātība. Bieži pušu paustās vēlmes l̦oti atškịiras no tā, ko tās patiešām grib. ${ }^{21}$

Ne mazāk nozīmīga par zināšanu un prasmju apguvi ir advokāta personība. Advokātam ir jāspēj vērot arī savu uzvedību un rīcību, jāaktivizē sevī spēja klausīties, izzināt un brīnīties, jāatsakās no vēlmes izteikt gatavus spriedumus, no ieraduma izdarìt secinājumus, izmantojot pagātnes pieredzi un model̦us, no uzskata, ka zina, kas klientam nepieciešams. Ir jāmācās domāt citādi - nolikt malā sacīkstes principu, kad katra puse cenšas pierādìt un argumentēt savu taisnību, lai panāktu trešãs puses (tiesas) klientam labvēlīgu lēmumu. Jāmaina stratēgija no cīņas un sacīkstes uz sadarbību, jāizprot tas, ka mediācijā katra puse pati ir atbildīga par strīda risinājumu.

19 Sternlight J. R. Lawyers' Representation of Clients in Mediation: Using Economics and Psychology to Structure Advocacy in a Nonadversarial Setting. Pieejams: https://kb.osu.edu/bitstream/ handle/1811/79967/OSJDR_V14N2_269.pdf?sequence=1 [aplūkots 2019. gada 9. maijā].

20 Blaustone B. Training the modern lawyer: incorporating the study mediation in required law school course. CUNY Academic Works, 1992. Pieejams: academicworks.cuny.edu/cgi/viewcontent. cgi?article $=1311 \&$ context=cl_pubs [aplūkots 2019. gada 9. maijā] .

${ }^{21}$ Hofmans R., Rotfišere D. B., Trosens A. Mediācija. Mediācijas pamati teorijā un praksē. Rīga: Tiesu namu aǵentūra, 2007, 9. lpp. 
Konfliktu risināšanas kultūra mainās, un, pieaugot mediācijas izmantošanai strīdu risināšanā, arī advokātiem ir jāapgūst arvien jaunas lomas un jābūt profesionālim gan tiesas zālē, gan mediācijas sarunu procesā.

\section{Kopsavilkums}

1. Advokāta loma mediācijā atkarīga no dažādiem aspektiem - lietas kategorijas, vienošanās ar klientu, pušu vienošanās par mediācijas dalỉbniekiem, arī advokāta zināšanām, pieredzes un personības. Advokāts mediācijā var būt gan mediators, gan mediācijas ieteicējs, gan konsultants un atbalsta persona, gan puses interešu pārstāvis.

2. Iesakot klientiem iekḷaut līgumos mediācijas klauzulu, informējot klientus par mediācijas iespējām, advokāti var būtiski veicināt mediācijas atpazīstamību un uzticēšanos tai.

3. Lai klientam sniegtu profesionālu atbalstu un konsultācijas mediācijas procesā, advokātam ir jāapgūst jaunas zināšanas, prasmes un uzvedỉbas modeḷi - piemēram, jāpārzina konfliktu risināšanas stratēǵija, mediācijas process un tajā izmantotās tehnikas, jāattīsta aktīvas klausīšanās prasmes, spēja atpazìt emocijas, empātija, radošums. Šìs zināšanas un prasmes nav reglamentētu noteikumu kopums, kas nozīmē, ka iespēja pilnveidoties ir neierobežota visā profesionālās karjeras laikā.

\section{BIBLIOGRĀFIJA}

\section{Literatūra}

1. Clark B. Lawyers and mediation. London: Springer, 2012.

2. Gereiša Z., Kirstuka L., Kḷave E. Mediācija. Jēdzieni. Testi. Lomu spēles. Mācību grāmata. Rīga: Tiesu namu aǵentūra, 2018.

3. Hofmans R., Rotfišere D. B., Trosens A. Mediācija. Mediācijas pamati teorijā un praksē. Rìga: Tiesu namu aǵentūra, 2007.

4. Litvins G. Advokātu process: neatbildētie jautājumi. Jurista Vārds, 2015. gada 7. aprīlis, Nr. 14 (866).

\section{Likumi un normativie akti}

5. Koncepcija “Mediācijas ieviešana civiltiesisku strīdu risināšanā”, Ministru kabineta 2009. gada 2. februāra rìkojums Nr. 121.

6. Latvijas Republikas Advokatūras likums: LV Likums. Latvijas Republikas Saeimas un Ministru Kabineta Ziņotājs, 1993. 19. augusts, Nr. 28.

7. Mediācijas likums: LV Likums. Latvijas Vēstnesis, 2015. 4. jūnijs, Nr. 108 (5168).

8. Ministru kabineta 2009. gada 10. marta noteikumi Nr. 227 "Zvērināta advokāta eksāmena kārtïba”: LR Ministru kabineta noteikumi. Latvijas Vēstnesis, 2009. 13. marts, Nr. 41 (4027).

9. Latvijas Zvērinātu advokātu ētikas kodekss. Pieņemts Latvijas Zvērinātu advokātu kopsapulcē 1993. gada 21. maijā; ar grozijumiem, kas izdarīti ar kopsapulces 30.04.2010. lēmumu; izteikts jaunā redakcijā, kas apstiprināts ar 2019. gada 12. aprị̣̄a kopsapulces lēmumu. 
10. Latvijas Zvērinātu advokātu padomes 2012. gada 13. novembra lēmums Nr. 259 "Par zvērinātu advokātu palīgu mācību programmu”.

\section{Interneta resursi}

11. Blaustone B. Training the modern lawyer: incorporating the study mediation in required law school course. CUNY Academic Works, 1992. Pieejams: academicworks.cuny.edu/cgi/viewcontent.cgi?article $=1311 \&$ context $=c 1$ pubs [aplūkots 2019. gada 9. maijā] .

12. Feehily R. The role of the lawyer in the commercial mediation process: a critical analysis of the legal and regulatory issues. Pieejams: https://www.academia.edu/36534721/The_Role_of_ the_Lawyer_in_the_Mediation_Process_A_Critical_Analysis_of_the_Legal_and_Regulatory_Issues [aplūkots 2019. gada 9. maijā].

13. Golann D. Mediation Advocacy. The role of Lawyers in Mediation. Pieejams: https://www. conflictdynamics.co.za/Files/129/Mediation-Advocacy--the-role-of-lawyers-in-mediation-.pdf [aplūkots 2019. gada 9. maijā].

14. Guidelines For Lawyers In Mediations. Law Council of Australia. Pieejams: file:///C:/Users/ user/Downloads/1108-Policy-Guideline-Guidelines-for-Lawyers-in-Mediations\%20(3).pdf [aplūkots 2019. gada 9. maijā].

15. Menkel-Meadow C. The Lawyer As Consensus Builder: Ethics For a New Practice. Pieejams: https://www.researchgate.net/publication/47505472_The_Lawyer_As_Consensus_Builder_Ethics_For_a_New_Practice [aplūkots 2019.gada 9. maijā] .

16. Sternlight J. R. Lawyers' Representation of Clients in Mediation: Using Economics and Psychology to Structure Advocacy in a Nonadversarial Setting. Pieejams: https://kb.osu.edu/bitstream/ handle/1811/79967/OSJDR_V14N2_269.pdf?sequence=1 [aplūkots 2019. gada 9. maijā].

17. Shako F. K. Teaching Old Dogs New Tricks: Can Lawyers Be Effective At Mediation? Pieejams: https://www.ajol.info/index.php/jolte/article/viewFile/113165/102888 [aplūkots 2019. gada 9. maijāa]. 